\title{
Child's Needs for a Healthy Development
}

\section{Mag Alina Georgeta*}

Lucian Blaga University of Sibiu, Romania

There are numerous classifications and theorizing of human needs. The theoretical variety, generated by the interest of researchers, signifies the importance of the needs in the functioning of the human being. One of the best known classifications of human needs is that proposed by Abraham Maslow and is part of the humanistic psychology. He represented the human needs in a pyramid structure with five levels: physiological needs, needs for safety and security, love and belonging needs, needs for self-esteem and axiological needs at the highest level, which causes self-development [1].

Maslow's theory is interesting for understanding motivation, the development and mental health of the individual. But "how well this theory covers the needs of healthy development of children today?" The desire to ensure a good childhood development and education is specific to civilized societies. It wasn't always thus. Disturbing evidence of childhood history confirms this: from the child treated as an adult in miniature, the child victim, abused and subjected to treatments of astonishing cruelty (infanticide and infant mortality was very high in past centuries), from the child used in employment, up to child's rights recognized by law and specific needs assessed, during development was dramatic. Halfway through the last century there was a real revolution in the vision of the child, to the attention of his needs manifested for a healthy development. Child's place in society has changed. Today he is considered the most valuable investment in the future [2].

In the last 50 years there has been a revolution of the physical care of the child. In the Psychology of human development Ana Munteanu considers the physiological children's needs are known and satisfied, but the same cannot be said about their psychological needs, "which cannot be met only through love and knowledge" [1]. If psychological needs should be respected, children would become stronger in order to adapt to a changing world, more emotionally balanced, better able to learn and happier to live together with others, in other words, more resilient.

Other more detailed classification of the most significant children's needs is the following: the need to be liked, loved, understood and accepted; the need for trust and freedom; the need for identity; need for stimulation and learning; the need for play and outdoor motion; the need for a healthy diet; need a daily routine; the need for discipline; need to be respected; the need for harmony [3].

Self-esteem plays one of the most important roles in the evolution and development of mental and emotional health of children. Efforts to increase low self-esteem are important for preventing future psychological problems. As the children become more sophisticated from a cognitive point of view, the self becomes more coherent, more stable, more realistic [4]. Numerous studies have shown that self-esteem is the only viable strategy to prevent most emotional or behavioral problems among children.

There is now a large body of scientific research that evaluates children's needs [4,5], analyzing the emotional and relational early experiences, in particular the effect of stressful experiences, when the little ones are deprived or care and stimulation are precarious. Children who are subject to a system of massive neglect, reared in orphanages, have had severe retardations in development, as a result of the treatment in early childhood.

The Centre of Knowledge on Healthy Child Development from
Oxford, also the Centre for Child Studies in Canada appreciate that today, globally, one in five children have health problems or emotional behavior. The consequences of these problems can last for life, and the costs to remedy the sudden difficulties are high. Children who grow up in families with tension, even though they are loved by both parents, can develop emotional disorders or to become antisocial. Similarly, teachers who do not build harmonious relations with the little ones or do not take account of their needs and using abusive criticism and punishment, have a profound impact negatively on their development [2].

In this context, the well-being of children resulting from the most significant needs for a healthy development is essential. If we do not respond adequately to the needs of children for a healthy development, we risk the future of the whole society. Gordon J and O Toole $\mathrm{L}$ recommends that all education systems take the well-being of children as their central purpose, because there are capacities, ranging from personal qualities to behavioral skills, which are necessary for the development of the personal resources to enable lifelong and lifewide learning [6]. In agreement with the above assertion, I appreciate that investment are needed in training teachers and parents' education focused on promoting the wellbeing of children.

\section{References}

1. Muntean A (2009) Psihologia dezvoltării umane. București: Editura Polirom.

2. Jones $P$ (2009) Rethinking childhood. Attitudes in Contemporary Society, New childhoods, New York:Continuum.

3. Dowling M (2010) Young children's personal, social and emotional development (Third Edition) London: Sage Publication Ltd.

4. Schaffer HR (2007) Introducere în psihologia copilului. Cluj - Napoca: Editura Asociația de științe Cognitive din România 319.

5. Clark A,Clarke A, Jessica Kingsley (2000) Early Experience and the Life Path. London

6. Gordon J, Toole OL (2015) Learning for well-being: creativity and inner diversity, Cambridge Journal of Education 45: 333-346.
*Corresponding author: Mag Alina Georgeta, Department of Private Law and Educational Sciences, lecturer PhD at Lucian Blaga University of Sibiu, Romania Tel: +40 269235224; E-mail: alina.mag@ulbsibiu.ro

Received February 20, 2016; Accepted February 22, 2016; Published February 29, 2016

Citation: Georgeta MA (2016) Child's Needs for a Healthy Development. J Psycho Abnorm S1: e003. doi:10.4172/jpab.S1-e003

Copyright: (๑) 2016 Georgeta MA. This is an open-access article distributed under the terms of the Creative Commons Attribution License, which permits unrestricted use, distribution, and reproduction in any medium, provided the original author and source are credited. 